\title{
Protecting Satire Against Libel Claims: A New Reading of the First Amendment's Opinion Privilege
}

\section{Leslie Kim Treiger}

From Aristophanes through Swift and Trudeau, satire has been an important mode of expressing political and social criticism. ${ }^{1}$ Satire is a literary form that employs such devices as sarcasm, irony and ridicule to deride prevailing vices or follies. ${ }^{2}$ It is particularly well-suited for political critique "because it tears down facades, deflates stuffed shirts, and unmasks hypocrisy. . . . Nothing is more thoroughly democratic than to have the high-and-mighty lampooned and spoofed."3 As early as 1917, one form of satire, cartoons, was identified as an effective medium for political speech. ${ }^{4}$ But while speech critical of government policies and public figures generally is accorded complete protection under the First Amendment" as "political speech," satire, which is critical of public figures and hence should be protected as political speech, ${ }^{7}$ is not adequately protected against libel claims.

Libel is governed by the "actual malice" standard established in New

1. See Hustler Magazine v. Falwell, 108 S. Ct. 876, 881 (1988) (describing historical use of graphic depictions and satirical cartoons, and noting that "our political discourse would have been considerably poorer without them"); see also Yorty v. Chandler, 13 Cal. App. 3d 467, 471, 91 Cal. Rptr. 709, 711 (1970) ("Ever since stone-age man began to draw on the walls of his cave, caricature has been used as a device to express opinion on matters of current interest. . . . From Daumier and Tenniel to Low and Herblock the political cartoon has occupied a central position in the presentation of critical comment on events and personages of the times.").

2. 9 Oxford English Dicrionary 119-20 (J. Murray, H. Bradley, W. Craigie \& C. Onions eds. 1961). The satiric form, however, has defied easy definition or characterization. PRINCETON Encyclopedia of PoETRy and Poetics 738 (A. Preminger ed. 1974). See also infra notes 101-111 and accompanying text.

3. Falwell v. Flynt, 805 F.2d 484, 487 (4th Cir. 1986) (Wilkinson, J., dissenting from denial of rehearing en banc).

4. Masses Publishing Co. v. Patten, 246 F. 24, 36 (2d Cir. 1917).

5. See New York Times Co. v. Sullivan, 376 U.S. 254, 269 (1964) ("The general proposition that freedom of expression upon public questions is secured by the First Amendment has long been settled by our decisions.").

6. G. Gunther, Constrtutional LAw 972 (11th ed. 1985) (speech critical of government officials and policies is political speech).

7. This Note addresses the problem of public figures because satire is topical and addresses issues of popular concern, see G. Highet, The ANATOMY of SATtRe 5 (1962), and thus often identifies public figures. But not all satire of public figures is "political" in the narrow sense of the term. See, e.g., Mr. Chow v. Ste. Jour Azur S.A., 759 F.2d 219, 230 (2d Cir. 1985) (restaurant considered public figure). "Political speech" is used here in a broader sense to mean commentary on society and its institutions generally. 
York Times Co. v. Sullivan, ${ }^{8}$ according to which public figures ${ }^{9}$ may recover only if the defendant's statement was intentionally false. Satire works through distortion; ${ }^{\mathbf{1 0}}$ it is, by definition, intentionally false. Although vulnerable to libel claims under the New York Times test, satire is not the sort of falsehood that the doctrine was designed to deter. The New York Times rule allows speakers to be found liable for intentionally making false statements of fact because such statements fail to contribute to the competition in the marketplace of ideas. ${ }^{11}$ But while satire presents a face both false and factual, it is not understood in a literal sense; it is not believed as false fact. ${ }^{12}$ Rather, beneath its factual face lies a critical message, which is satire's essence. Audiences understand this essence, and read satire as opinion rather than as literal fact.

In Gertz v. Robert Welch, Inc., ${ }^{13}$ the Supreme Court carved out an exception to the New York Times standard that could be used to rescue satire from its quandary. Under Gertz, opinions are protected even where defamatory. ${ }^{14}$ But as the opinion privilege has been interpreted by lower courts, only very exaggerated forms of satire are clearly protected: fictions, hyperbole, allegories, cartoons, epithets and nonsensical fantasies. ${ }^{16}$ The most realistic satire, ${ }^{16}$ which is often the sharpest satire, does not fall into any of these categories.

With no clear standard, courts have protected satires only after numerous appeals, and then only by applying ad hoc, clumsy, and non-uniform rationales. ${ }^{17}$ This Note argues that the opinion privilege must be understood to immunize satirical critiques of public figures against libel claims, and suggests a test to facilitate courts' assessments of realistic political sat-

8. 376 U.S. 254, 279-80 (1964). See infra notes 28-29 and accompanying text.

9. New York Times applied to public officials, but its rule was soon extended to public figures generally. Curtis Publishing Co. v. Butts, 388 U.S. 130 (1967), interpreted in Gertz v. Robert Welch, Inc., 418 U.S. 323, 335-37 (1974).

10. L. Feinberg, The Satirist: His Temperament, Motivation, and Influence 7 (1965).

11. See Garrison v. Louisiana, 379 U.S. 64, 75 (1964) (deliberate lie has little value as step to truth and is at odds with orderly change and with premises of democratic government). While "there is no constitutional value in false statements of fact," some factual error is inevitable, Gertz, 418 U.S. at 340 , and must be tolerated in order to give necessary " "breathing space" " to freedoms of expression, New York Times, 376 U.S. at 271-72 (citations omitted).

Satire may be defended under the First Amendment rationale that speech should be protected to ensure a wide range of public debate in an effort to arrive at truth, but also under the "representative democracy" and "individual autonomy" rationales. See G. GuNTHER, supra note 6, at 978-79.

12. Reading satire requires a rejection of what the author or speaker seems to say in her surface message. W. BOOTH, A RHeToric of IRONY 1, 6, 10, 24, 33 (1974).

13. 418 U.S. 323 (1974). See infra notes $46-48$ and accompanying text.

14. 418 U.S. at 339-40. The constitutional protection for opinion has replaced the common law "fair comment" doctrine which privileged the expression of opinion on matters of public concern. $R$. SaCk, Libel, Slander and Related Problems 164, 180-83 (1980).

15. See infra notes $38-79$ and accompanying text.

16. Satire aims at realism, see G. HIGHET, supra note 7 , at 5 , which involves mimicking reality to the point of appearing to be a presentation of true fact. See also infra note 44 and accompanying text; cf. R. Lanham, The Motives of Eloquence 7, 17 (1976) (rhetorical narrative and satire are mimetic of an obverse reality).

17. See infra notes $28-83$ and accompanying text. 
ire. Section I discusses the importance of giving satire aimed at public figures absolute protection, even at the expense of reputational interests. Section II argues that none of the current characterizations of the standard can adequately protect realistic satires from liability. In Section III, this Note develops a standard for a "satire category" of the opinion privilege, using hermeneutics as a guide. Hermeneutics, the study of meaning, is a helpful tool for investigating what satire means, and thus how courts should treat it. According to many contemporary hermeneutics theorists, the proper focus for an inquiry into the process of deriving meaning is on the reader's understanding of the material rather than the author's intent. ${ }^{18}$ Thus, liability should be imposed not where the author intends to falsify, but where readers believe the statement as fact rather than as opinion.

\section{Satire and Libel: Balancing Free Speech and Reputation}

Libel law sanctions speech that is defamatory-speech that "tends to expose [one] 'to public contempt, ridicule, aversion or disgrace, or induce an evil opinion of him in the minds of right-thinking persons, and to deprive him of their friendly intercourse in society." "19 The doctrine has been developed in order to protect individuals' interest in reputation. ${ }^{20}$ Libel law often comes into conflict, however, with the First Amendment's protection of free speech. In these situations, courts have recognized the need to weigh the plaintiff's interest in reputation against the defendant's First Amendment right, but have held that the right to speak critically of public figures must prevail. ${ }^{21}$

In upholding the speaker's First Amendment right, courts have discussed a number of factors. First, courts have emphasized the importance

18. Legal scholars have applied hermeneutics to evaluate theories of constitutional interpretation or law's interpretive methods generally. See, e.g., Powell, The Original Understanding of Original Intent, 98 HARv. L. REv. 885 (1985); Interpretation Symposium, 58 S. CAL. L. REv. 1 (1985) Symposium: Law and Literature, 60 TEx. L. REv. 373 (1982). Some of these theorists have argued for looking to the interpretation of the reader, or community as a whole, to find the meaning of a text. See, e.g., S. Fish, Is There a TeXt In THIS Class? (1980); Cover, The Supreme Court, 1982 Term-Foreword: Nomos and Narrative, 97 HARv. L. REv. 4 (1983); see also infra notes 87-89 and accompanying text. This Note approaches a specific legal doctrine with similar hermeneutic tools, and explores the implications.

Hermeneutics is particularly useful as applied to the tort of libel, which involves communication. A concern about reputation is a concern about the community's perception of an individual member of that group. See infra note 90 and accompanying text. Hermeneutics can aid the law by identifying the meaning that satire has for its community of readers.

19. Frank v. National Broadcasting Co., 119 A.D.2d 252, 255, 506 N.Y.S.2d 869, 871 (1986) (quoting Sydney v. Macfadden Newspaper Publishing Co., 242 N.Y. 208, 211-12, 151 N.E. 209, 210 (1926)).

20. See Rosenblatt v. Baer, 383 U.S. 75, 86 (1966).

21. See, e.g., Philadelphia Newspapers v. Hepps, 475 U.S. 767, 776 (1986) (where "scales are in such an uncertain balance" as to whether allegedly defamatory statement is true or false, "the Constitution requires us to tip them in favor of protecting true speech"). Of course, the protection is not absolute; speakers may be held liable where constitutional boundaries have been transgressed. See infra notes 28-29 and accompanying text. 
of vigorous public debate. ${ }^{22}$ Without clear safeguards, this vital discourse may be chilled by the threat of a lawsuit. Such self-censorship by potential defendants is a very real burden; courts and commentators have stressed the need to make writers less fearful of libel suits. ${ }^{23}$

Second, public figures are said to have assumed the risk of being attacked by voluntarily entering public life. ${ }^{24}$ The individual who thrusts herself into the public eye must be prepared to face some abuse. ${ }^{25} \mathrm{~A}$ third argument courts have offered for preferring speakers' rights to plaintiffs' reputational interests is that public figures have means of "self help": Public figures can use the media to combat reputational harm. Private figures, by contrast, do not enjoy access to the media to the same extent. ${ }^{26}$

For these reasons, courts have developed a doctrine that protects true fact and opinion-even where defamatory ${ }^{27}$-from libel claims. The appropriate threshold question for satire therefore is not whether it is true fact or defamatory but whether it is protected opinion.

\section{The Gurrent Standard}

\section{A. The New York Times Rule}

In New York Times Co. v. Sullivan, ${ }^{28}$ the Supreme Court established a three-part test to protect critics of official conduct from libel suits. To establish a claim, the plaintiff must show that the defendant published (1) a false statement of fact (2) having defamatory content with (3) "actual malice," defined as knowledge of falsity or reckless disregard for the truth. ${ }^{29}$ Because satire works through distortion of the familiar-while at the same time pretending to depict reality -in order to level criticism, ${ }^{30}$ it fails to gain protection under any of the three prongs of this standard. First, because it works through distortion, satiric material easily can be identified as falsity or, at best, exaggeration. Moreover, by definition satire often, on its face, has the appearance of fact. Second, satirical material

22. See New York Times Co. v. Sullivan, 376 U.S. 254, 270 (1964) (describing national commitment to maintaining "uninhibited, robust, and wide-open" debate).

23. See, e.g., Gertz v. Robert Welch, Inc., 418 U.S. 323, 340 (1974); id. at 365-66 (Brennan, J., dissenting); Gora, Introduction: Literature, Life, and the Law, in Symposium: Defamation in Fiction, 51 BROOKLYN L. Rev. 225, 230 (1985).

24. Gertz, 418 U.S. at 345.

25. As President Harry Truman put it: "If you can't stand the heat, don't go in the kitchen." Silsdorf v. Levine, 85 A.D.2d 297, 302, 447 N.Y.S.2d 936, 939 (1982); see also Ollman v. Evans, 750 F.2d 970, 1002 (D.C. Cir. 1984) (en banc) (Bork, J., concurring) (individual deliberately entering arena where ideas about politics contend must expect rough and personal debate), cert. denied, 471 U.S. 1127 (1985).

26. Gertz, 418 U.S. at 344.

27. See Old Dominion Branch No. 496, Nat'l Ass'n of Letter Carriers v. Austin, 418 U.S. 264, 285 n.10 (1974) (true facts can create reputational harm, but are nonetheless protected); Gertz, 418 U.S. at 339-40 (although opinions can damage reputations, they are nonetheless protected).

28. 376 U.S. 254 (1964).

29. Id. at 271-72 (false fact); id. at 272-73 (defamatory); id. at 279-80 (actual malice).

30. L. FeINBERG, supra note 10 , at 7 . 
is critical of its subject's character or actions, and hence may be defamatory. Finally, the satirist always writes with "actual malice," since she intends the falsity or exaggeration of her statement.

Realistic satire, which is most vulnerable to liability under this standard, was at issue in Hustler Magazine v. Falwell. ${ }^{31}$ In that case, Reverend Jerry Falwell brought suit against Larry Flynt and Hustler Magazine for a parody based on the "first time" slogan used in Campari Liquor advertisements. In the Hustler version, which was printed in the format of an interview, Falwell's "first time" was an incestuous encounter with his mother in an outhouse in Lynchburg, Virginia. ${ }^{32}$ The piece was clearly recognizable as satire: It distorted the familiar (the well-known Reverend was depicted as sexually perverse) with the pretence of reality (in the interview format) to convey an underlying critical message (that Falwell is a hypocrite). Although this satire was a critical statement about a public figure ${ }^{33}$ and hence should have been protected as political speech expressed through opinion, it engendered a complicated libel suit; there was no clear way to protect the speech because of its satirical form. Falwell argued that the piece was intentionally false, seemingly factual and defamatory, ${ }^{34}$ and thus violated the New York Times rule. The jury in the district court dismissed the libel claim not on the basis of the New York Times test nor on a finding that the parody was protected opinion, but simply on the grounds of its unbelievability. ${ }^{36}$ A "believability" test offers weak protection for realistic satire, which is often believable in the sense that it is not impossible fantasy, but nonetheless is not actually $b e-$ lieved. ${ }^{36}$ The Supreme Court's decision in Hustler overturned the large sum in damages awarded by the jury to Falwell for the tort of intentional infliction of emotional distress, ${ }^{37}$ but did little to resolve the underlying ambiguity.

While satire violates the New York Times actual malice test, another form of literary falsehood, fiction, generally has found protection under the standard. ${ }^{38}$ Fiction, defined broadly, is "fabrication" or "invention of

31. 108 S. Ct. 876 (1988).

32. Hustler Magazine, Nov. 1983, at 2 (inside front cover), reprinted in Brief for Respondent at Appendix E, Hustler Magazine and Flynt v. Falwell, 108 S. Ct. 876 (1988) (No. 86-1278). The disclaimer "ad parody-not to be taken seriously" was printed at the bottom of the page.

33. The parties did not dispute the fact that Falwell was a public figure. Hustler, $108 \mathrm{~S}$. Ct. at 882 \& n.5.

34. Brief for Respondent, supra note 32, at 24-29, 33-35.

35. Falwell v. Flynt, 797 F.2d 1270, 1273 (4th Cir. 1986), rev'd sub nom. Hustler Magazine v. Falwell, 108 S. Ct. 876 (1988). See infra note 70.

36. The believability standard presents numerous other problems as well. See infra notes 65-72 and accompanying text.

37. Hustler, $108 \mathrm{~S}$. Ct. at 882 . On appeal, the Court extended the stringent New York Times libel standard to this alternative tort. The New York Times standard is as problematic for satire under this tort as it is for libel: The satirist often sharpens her spear and aims to distress quite intentionally. See infra note 114.

38. On the problems of fiction under libel law, see R. SACK, supra note 14, at 66, 238, 247; Symposium, supra note 23. 
the imagination." ${ }^{39}$ Satire can be viewed as a subset of fiction-as one kind of fabrication. Fiction and satire both face liability under libel law because they are intentionally false ${ }^{40}$ and attempt to convey their falsity in a believable fashion, although they are not generally believed by readers.

Fiction has gained protection for a different reason, however. The fiction writer usually does not intend to identify and defame publicly-known individuals ${ }^{41}$ in the same way that the satirist does. As a result, fiction generally escapes liability by not meeting the "of and concerning" requirement of the actual malice rule, ${ }^{\mathbf{4}}$ according to which a speaker may not be found liable unless her statement identifiably concerns the plaintiff, or it is at least shown that she intended such an identification..$^{43}$ Most satire, intentionally poking fun at real people, real issues and real events, ${ }^{44}$ could not be protected by the "of and concerning" defense. ${ }^{45}$

\section{B. The Opinion Privilege}

The opinion privilege grew out of the New York Times requirement that only false statements about public figures can give rise to libel claims. The Supreme Court reasoned in Gertz v. Robert Welch, Inc. that statements of opinion are protected from defamation suits by the First Amendment because, unlike statements of fact, they can never be false: "Under the First Amendment there is no such thing as a false idea. However pernicious an opinion may seem, we depend for its correction not on the conscience of judges and juries but on the competition of other ideas." ${ }^{\text {"4 }}$

39. 4 OXford ENGlish Dictionary, supra note 2, at 111.

40. Fiction is "false" in the sense that it is invention and not literally true; at the same time, it is like satire in not purporting to be true in a literal sense.

41. See R. Posner, Law and Literature: A Misunderstood Relation 324 (1988) (literature uses private figures).

42. For a discussion of the "of and concerning" requirement, see Note, Libel and Fiction, 92 YALE L.J. 520 (1983).

43. See, e.g., Miss America Pageant v. Penthouse Int'l, Ltd., 524 F. Supp. 1280, 1282 (D.N.J. 1981) (protecting parody of Miss America contest on basis of finding that defendant had not intended story to resemble real person or event; rejecting defendant's contention that work should receive protection as humor, satire or opinion). Fiction, however, has not been awarded absolute protection. Id. at 1281. In one unusual case, a court found that a fictional work was "of and concerning" the plaintiff, and imposed liability. Bindrim v. Mitchell, 92 Cal. App. 3d 61, 155 Cal. Rptr. 29, cert. denied, 444 U.S. 984 (1979).

44. Worcester, The Satiric Spectrum, in Satire: Modern Essays In CRITICISM 318 (R. Paulson ed. 1971) (satire distinguished from comedy by presence of "the historically authentic and the historically particular").

45. In hearing a libel suit based on a magazine's satiric comment about Jimmy Myers, a television sports announcer, the court in Myers $v$. Boston Magazine Co. recognized the crucial difference between these two literary forms: "[I]nsofar as it appears on its face to be a statement of fact, the ironic statement here resembles an assertion in a fictional narrative. . . . On the other hand, the Boston Magazine statement differs from one in a short story or novel: it purports to be about the real Jimmy Myers." Myers v. Boston Magazine Co., 380 Mass. 336, 344 n.8, 403 N.E.2d 376, 381 n.8 (1980).

46. 418 U.S. 323, 339-40 (1974); see also Abrams v. United States, 250 U.S. 616, 630 (1919) (Holmes, J., dissenting) ("the best test of truth is . . . in the competition of the market"). 
Although this language is only dictum, ${ }^{47}$ federal courts have treated it as controlling ${ }^{48}$ and have exempted statements of opinion from liability under libel claims. Beyond establishing the legal distinction between fact and opinion, however, the Supreme Court has provided little guidance in determining when statements fall into one category or the other. In grappling with the problem, lower courts have developed a number of interpretations of the opinion privilege. While each may provide protection for certain satiric forms, none is adequate to protect realistic political satire.

\section{Ollman v. Evans: The Totality of Circumstances Test}

In Ollman v. Evans, ${ }^{48}$ a plurality of the D.G. Circuit developed the "totality of circumstances test" for distinguishing between fact and opinion. ${ }^{.0}$ The court examined three elements: the verifiability of the statement; the common usage or meaning of the specific language; and the context, in terms of both the surrounding language and the setting.

In Mr. Chow v. Ste. Jour Azur S.A., ${ }^{\text {s1 }}$ the Second Circuit relied on the first prong of the Ollman test to evaluate derogatory statements in a review about the food in a Chinese restaurant, ${ }^{52}$ and held all but one comment to be protected opinion. ${ }^{53}$ The court found that because of their hyperbolic style, the statements could not be taken literally and hence were not verifiable-they were incapable of being proved true or false. ${ }^{54}$ But realistic satire, which presents itself in factual, literal form, is often verifi-

47. The Supreme Court's holding in Gertz, that private figures need not be held to the actual malice standard required of public figure claimants, did not depend on an application of the factopinion distinction. 418 U.S. at 347.

48. See Ollman v. Evans, 750 F.2d 970, 974-75 n.6 (D.C. Cir. 1984) (en banc) (listing decisions of various circuits treating Gertz dictum as controlling law), cert. denied, 471 U.S. 1127 (1985).

49. 750 F.2d at 979 . The Ollman litigation developed out of a newspaper column by Rowland Evans and Robert Novak which termed a professor a "Marxist." The court held that this and other statements were entitled to absolute First Amendment protection as expressions of opinion.

50. The Ollman court relied, see id. at $977 \&$ n.12, 982 , on the holding of Information Control v. Genesis One Computer Corp., 611 F.2d 781, 784 (9th Cir. 1980) (in determining whether statement is fact or opinion, courts should "examine the statement in its totality in the context in which it was uttered or published": all words used, any cautionary terms, and all circumstances surrounding statement, including medium used and audience addressed).

51. 759 F.2d 219 (2d Cir. 1985).

52. The statements included: "the green peppers . . . remained still frozen on the plate" and the "pancakes [were] the thickness of a finger." Id. at 221-22.

53. The one statement that the court held to be defamatory fact involved a numerical reference, and hence was easily verifiable: "[T]he Peking lacquered duck . . . was made up of only one dish (instead of the three traditional ones)." Id. at $222,229$.

54. Id. at 229; see also Buckley v. Littell, 539 F.2d 882 (2d Cir. 1976) (phrase " 'fellow traveler' of 'fascism' " protected because open to many interpretations and unverifiable), cert. denied, 429 U.S. 1062 (1977).

The verifiability factor grows directly out of the Gertz rationale. Opinion is protected because it cannot be false; a statement therefore should be protected if it cannot be understood as true or false. See Ollman, 750 F.2d at 981 ("a reader cannot rationally view an unverifiable statement as conveying actual facts"). One commentator suggests that the verifiability standard best serves the purposes of the First Amendment and is the most predictable and easily administered test for distinguishing between fact and opinion. Note, Statements of Fact, Statements of Opinion, and the First Amendment, 74 Cal.if. L. Rev. 1001, 1029-31, 1045 (1986). 
able and easily proven false. For example, such a test would indict the seemingly literal satire in question in Hustler as false, verifiable fact, since Reverend Falwell probably has not committed incest with his mother in an outhouse.

With regard to the next factor of its test, the common usage and meaning of the language, the Ollman court questioned whether the statement in dispute had a precise core of meaning or was indefinite. The D.C. Gircuit explained that "[r]eaders are . . . less likely to infer facts from an indefinite or ambiguous statement than one with a commonly understood meaning." ing "The Mugging of the Muse," allegedly depicting the plaintiffs as muggers, which was the subject of a libel suit in Silberman $v$. Georges. ${ }^{56}$ The realistic satire at issue in Hustler, however, used precise words with clear meaning; because the language was not obviously symbolic, Hustler would have been found liable under this test.

The final element of the Ollman test, consideration of context, ${ }^{67}$ has been used by a number of courts to protect satirical cartoons. The form of cartoons, often comic strips, and their setting, in obviously humorous or fantastical works, makes it clear that their statements cannot be taken literally as statements of fact, and thus are not considered libelous. ${ }^{58}$ Realistic satire cannot be protected under this interpretation of the opinion rule. In Hustler, the form of the parody was an interview, and the setting was a magazine that included factual reporting.

\section{Rhetorical Hyperbole}

Using an approach distinct from the Ollman test-but also looking closely at the language of the text and the context of statements-courts have identified expressions in the form of "rhetorical hyperbole" as protected opinion..$^{58}$ This category was developed in Greenbelt Cooperative Publishing Association v. Bresler to protect the use of the term "black-

55. 750 F.2d at 979 .

56. 91 A.D.2d 520, 456 N.Y.S.2d 395 (1982). The Silberman court also referred to the closely related rhetorical hyperbole doctrine. See infra note 62 and accompanying text.

57. Traditional common law tort standards recognized the importance of context. See RestateMENT (SECOND) OF TORTS $§ 563$ comment $f$ (1977) ("inducement" explores narrative of extrinsic circumstances, "colloquium" connects words with circumstances disclosed in inducement and "innuendo" interprets meaning of language in light of surrounding circumstances). In addition to the textual context of the statement, Ollman implies that the broader social context also should be examined. 750 F.2d at $983-84$.

58. See, e.g., Dworkin v. Hustler Magazine, 668 F. Supp. 1408, 1415-16 (C.D. Cal. 1987), affd, 867 F.2d 1188 (9th Cir. 1989); King v. Globe Newspaper Co., 12 Media L. Rep. (BNA) 2361, 2367 (Mass. Super. C.t. 1986), aff'd in part and rev'd in part, 512 N.E.2d 241 (Mass. 1987), cert. denied, 108 S. Ct. 1121 (1988).

59. According to one commentator, it is not clear whether rhetorical hyperbole is protected because it can cause no reputational harm, because it is opinion or because courts should not intervene in something as trivial as name-calling. R. SACK, supra note 14 , at 58 . This Note assumes for the discussion that protection of rhetorical hyperbole is a facet of the opinion privilege. 
mail" in the context of full and accurate reporting of a public debate. ${ }^{.00}$ The doctrine also has been used to immunize the epithet "traitor," method of allegoric representation ${ }^{62}$ and the exaggeration used in satirical cartoons. ${ }^{63}$ Again, this test fails to protect satire that, in trying to be as realistic as possible, avoids using hyperbolic language. ${ }^{64}$

\section{Believability, Absurdity and Humor}

Even more problematic for satire is the interpretation some courts have given the Gertz opinion privilege as indicating that the appropriate inquiry is into the believability of a communication. The Silberman court, for example, protected artwork it called "fanciful" because the art lacked realism. ${ }^{65}$

The test developed in Pring $v$. Penthouse International, $L t d .^{68}$ uses a similar standard for determining not whether a statement is opinion, but whether it is defamatory. In Pring, the court asked "whether the charged portions in context could be reasonably understood as describing actual facts about the plaintiff." ${ }^{\prime \prime 7}$ Only if the statement could be so understood would it be subject to liability.

Pring, however, involved an "impossibility and fantasy within a fictional story." zine based on a story in which a baton-twirling Miss Wyoming was engaged in sexual acts with her coach that caused him to levitate on stage during the Miss America Pageant. While in Pring, and in other very

60. 398 U.S. 6,14 (1970).

61. Old Dominion Branch No. 496, Nat'l Ass'n of Letter Carriers v. Austin, 418 U.S. 264, 285-86 (1974); see also Loeb v. Globe Newspaper Co., 489 F. Supp. 481, 486 (D. Mass. 1980) (plaintiff "runs a paper by paranoids for paranoids"); National Ass'n of Gov't Employees v. Central Broadcasting Corp., 379 Mass. 220, 228-30, 396 N.E.2d 996, 1001-02 (1979) ("inroads of communism"), cert. denied, 446 U.S. 935 (1980).

62. Silberman v. Georges, 91 A.D.2d 520, 521, 456 N.Y.S.2d 395, 397 (1982).

63. See, e.g., Keller v. Miami Herald, 11 Media L. Rep. (BNA) 1032, 1033 (S.D. Fla. 1984); Yorty v. Chandler, 91 Cal. Rptr. 709, 715, 13 Cal. App. 3d 467, 476-77 (1970). Some courts have combined the text-in-context interpretation of the opinion privilege with the rhetorical hyperbole category to call cartoons opinions. See, e.g., Keller v. Miami Herald Publishing Co. (Keller II), 778 F.2d 711, 715, 717-18 (11th Cir. 1985); Franklin v. Friedman, 12 Media L. Rep. (BNA) 1146, 1147-48 (N.Y. Sup. Ct. 1985).

64. See Myers v. Boston Magazine Co., 380 Mass. 336, 344, 403 N.E.2d 376, 380 (1980) (noting inapplicability of rhetorical hyperbole test for language without "familiar figurative sense" or which is not "too amorphous").

65. 91 A.D.2d at 521,456 N.Y.S.2d at 397

66. 695 F.2d 438 (10th Cir. 1982).

67. Id. at 442 . The Restatement, supra note 57 , at $\$ 563$, uses a similar formulation in defining the meaning of a communication for libel law purposes as "that which the recipient correctly, or mistakenly but reasonably, understands that it was intended to express" (emphasis added). Many other courts have followed Pring or used similar language. See, e.g., Koch v. Goldway (Koch II), 817 F.2d 507, 509 (9th Cir. 1987); Lane v. Arkansas Valley Publishing Co., 675 P.2d 747, 750 (Colo. Ct. App. 1983), cert. denied, 467 U.S. 1252 (1983); Myers v. Boston Magazine Co., 380 Mass. 336, 340, 403 N.E.2d 376, 378-79 (1980); Moreno v. Time, 11 Media L. Rep. (BNA) 2196, 2199 (N.Y. Sup. Ct. 1985).

68. 695 F.2d at 441. The Pring case arose out of the same facts as Miss America Pageant v. Penthouse Int'l, Ltd., 524 F. Supp. 1280 (D.N.J. 1981); see supra note 43. 
exaggerated forms of unbelievable fantasy, the acts depicted are physically impossible, more realistic satire easily could be said to depict "actual facts." Such a piece could be denied protection because it is believable, even though it is not actually believed by its readers. Indeed, in a dissent to the Pring decision, one judge argued that "[f]ellatio is not [a fiction]. It is a physical act, a fact, not a mental idea."

The lower court in Falwell v. Flynt used a test similar to the Pring standard and successfully protected the more realistic satire; the jury found the piece unbelievable. ${ }^{70}$ The test, however, poses a number of problems. First, with reasoning following the dissent in Pring, the jury might have found that incest is a fact, not a fiction. Second, this test allows liability for statements with which libel law should not be concerned; no serious reputational harm can befall the target of a satire which is plausibly believable but is not actually believed as fact.

A third problem is that pursuant to the language used in Hustler and Pring, realistic satire easily could be interpreted as describing facts, ${ }^{\mathbf{7 1}}$ since satire indeed purports to do just that. Under this standard, Falwell could argue that the parody clearly describes as fact that the Reverend slept with his mother. The Court should have focused not on what the author and text seem to do, but on whether the readers believed the statements to be facts.

Finally, the Supreme Court's opinion in Hustler provides a weak precedent. The Court protected the parody based on the New York Times rule, which is inappropriate for satire, and on a finding that the parody was non-defamatory, although satire often aims to and succeeds in defaming its target. Protection based on the constitutional ground of the opinion privilege would have been much stronger ${ }^{72}$ While the Supreme Court's opinion in Hustler was hailed as a great victory for the First Amendment, the standard it established is inadequate for protecting realistic satire.

A test equally as dangerous as a "believability" standard is measuring the laughter inspired by the material. Some courts have set the level of protection afforded to a work according to how funny the judge thinks it

69. 695 F.2d at 443-44 (Breitenstein, J., dissenting).

70. The district court asked the jurors whether the material could be understood as describing actual facts about the plaintiff or actual events in which he participated. The jury responded in the negative. Falwell v. Flynt, No. 85-1417(L) slip op. App. C, at 1 (W.D. Va. 1986). The Fourth Circuit interpreted this language as a "reasonably believable" rule, 797 F.2d at 1273, 1278, and the Supreme Court accepted the characterization, $108 \mathrm{~S}$. Ct. at 882-83.

71. Hustler, 108 S. Ct. at 879 ("stating actual facts"); Pring, 695 F.2d at 442 ("describing actual facts").

72. The Court repeated the Gertz dictum that there can be no "false idea," but again only as dictum. $108 \mathrm{~S}$. Ct. at 879 . According to the lower court, the argument that the satire was opinion was "irrelevant in the context of this [alternative] tort," 797 F.2d at 1276; the Supreme Court noted this holding without explicitly rejecting it, $108 \mathrm{~S}$. Ct. at 879 . Justice White, in concurrence, noted that New York Times has little to do with the case because the jury found that the advertisement contained no statements of fact. Id. at 883 . But nowhere in the opinion is the satire directly called opinion. 
is. In Frank v. National Broadcasting Co. ${ }^{73}$ the fact that the humor of a Saturday Night Live skit was "so extremely nonsensical and silly" was a critical factor in the court's determination that the allegedly libelous statements were protected, again not as opinion, but as non-defamatory. ${ }^{74} \mathrm{Sa}$ lomone v. MacMillan Publishing Co. ${ }^{75}$ went even further and held humor to be categorically protected. ${ }^{78}$ Most courts, however, have rejected this view and held that comedy is not per se immune from a defamation action: ${ }^{77}$ While humor is often a form of criticism or social commentary, ${ }^{78}$ one cannot escape liability for "murder[ing] another's reputation in jest."'?ק

Courts' rejection of the use of a humor meter in determining protection for a statement is wise. Such a standard would be too subjective; what Hustler readers find humorous is quite different from what will make Moral Majority members laugh. Moreover, while most satire contains some humor, this approach would not suffice to protect satire that either is more serious or simply falls flat in its attempt at humor. Courts may consider a piece's humor as one factor in finding that it is satire, but should never deny it the protection that would be afforded a satirical statement solely because it lacks humor.

\section{The Restatement Approach}

The Restatement (Second) of Torts Section 566 outlines an approach for distinguishing fact from opinion under which an opinion is actionable

73. 119 A.D.2d 252, 506 N.Y.S.2d 869 (1986).

74. 119 A.D.2d at 261,506 N.Y.S.2d at 875. Similarly, the court in Franklin v. Friedman stated that a magazine's comic strip showing the plaintiff visibly shrinking was "not serious and/or factual." 12 Media L. Rep. (BNA) 1146, 1147 (N.Y. Sup. Ct. 1985). By conflating the two terms, this court failed to realize that much satire is serious but not, except facially, factual. See also Myers v. Boston Magazine Co., 380 Mass. 336, 342, 403 N.E.2d 376, 380 (1980) (stating that satiric jokes of performer could not be called "attempts to persuade"); RestaTEMENT, supra note 57 , at $\$ 566$ comment d (calling non-defamatory a statement of "good-natured fun, not intended to be taken seriously").

75. 97 Misc. 2d 346, 350, 411 N.Y.S.2d 105, 108-09 (1978), rev'd, 77 A.D.2d 501, 429 N.Y.S.2d 441 (1980).

76. In Salomone, a parody of a storybook character who lived at the Plaza Hotel depicted the young girl twenty years later scribbling with pink lipstick on a mirror in the Hotel that the manager, Mr. Salomone, was a child molester. Mr. Salomone, the real-life manager, filed a libel suit. The court left it to the jury to determine whether the words constituted "nonactionable humor or compensable libel." 97 Misc. 2d at 352, 411 N.Y.S.2d at 110. Interestingly, the Salomone court excepted from its protection a statement intended to be funny but not found by its readers to be so. 97 Misc. $2 \mathrm{~d}$ at 351 , 411 N.Y.S.2d at 109-10. Although the plaintiff's claim was ultimately dismissed for the absence of a showing of actual malice or reputational harm, the appeals court did not disturb the lower court's test. 77 A.D.2d 501, 429 N.Y.S.2d 441.

77. See, e.g., Dworkin v. Hustler Magazine, 668 F. Supp. 1408, 1413 n.4 (C.D. Cal. 1987), affd, 867 F.2d 1188 (9th Cir. 1989) (citing Polygram Records v. Superior Court, 170 Cal. App. 3d 543, 216 Cal. Rptr. 252 (1985) and Frank, 119 A.D.2d 252, 506 N.Y.S.2d 869); see also R. SACK, supra note 14, at 65-66 (humor gives rise to causes of action).

78. Polygram, 170 Cal. App. 3d at 552-53, 216 Cal. Rptr. at 258; R. SACK, supra note 14, at 239. See also Winters v. New York, 333 U.S. 507, 510 (1947) ("What is one man's amusement, teaches another's doctrine.").

79. Frank, 119 A.D.2d at 257, 506 N.Y.S.2d at 872 (citing Donoghue v. Hayes, Hayes Irish Exchequer Rep. 265, 266 (1831)). 
only if it implies the allegation of nondisclosed defamatory facts as the basis for the opinion. For example, if A writes to B, "I think $G$ is an alcoholic," a jury might find the statement an expression of opinion but also one which implies that $A$ knows undisclosed facts to support her opinion. ${ }^{80}$ The problem for satire lies in its presentation of a front of making factual assertions, even though those assertions are not actually believed. For example, the court in Hustler might have found liability under the Restatement test because the piece could be understood to imply that Flynt knew something about Falwell's private life that the reader does not know. ${ }^{81}$ However, liability would be inappropriate, since it is unlikely that the readers of the satire would believe the truth or even existence of such undisclosed facts. ${ }^{\mathbf{2}}$

As the discussion above illustrates, fictions, hyperbole, allegories, cartoons, epithets, fantasies and comedy are protected by current doctrine, but realistic satires about public figures, which function as political speech, remain vulnerable to libel claims. ${ }^{83}$ Courts should develop a more coherent approach to protect satire as opinion.

80. Restatement, supra note 57 , at $\$ 566$ comment c, illustration 3; see also Killington Ltd. v. Times Argus, 14 Media L. Rep. (BNA) 1314, 1316 (Vt. Super. Ct. 1987) (using Restatement test to distinguish between "pure" opinion on one hand and "mixed" opinion-that based on facts not stated in communication or assumed to exist by parties to communication-on other). The court in Ollman $v$. Evans remarked that the Restatement test is both unnecessary, because the factors of textual language and verifiability perform the same function, and inadequate, because a statement can be understood as opinion even where no facts are disclosed. 750 F.2d 970, 984-85 (D.C. Cir. 1984) (en banc), cert. denied, 471 U.S. 1127 (1985).

81. Reverend Falwell indeed argued that the Hustler parody should be actionable because it failed to disclose the facts underlying the opinion. Brief for Respondent, supra note 32, at 38-39.

82. The Restatement view may be useful for textual examination of satire; see infra notes 101-11 and accompanying text, if it is underscored that the underlying message is being examined, not the factual assertion on the face of the text, see infra note 111, and that in the case of public figures, the facts upon which opinions are based are generally known, see Myers v. Boston Magazine Co., 380 Mass. 336, 341, 403 N.E.2d 376, 379 (1980); Killington, 14 Media L. Rep. (BNA) at 1316. The Restatement view, however, still would slight the reader's interpretation of the statement.

83. The recent case of Dworkin v. Hustler Magazine, 668 F. Supp. 1408 (C.D. Cal. 1987), affd, 867 F.2d 1188 (9th Cir. 1989), exemplifies the confusion courts face in applying the New York Times rule and the opinion privilege to political satire. Andrea Dworkin, a widely-known feminist, sued Hustler Magazine for its publication of a series of sexually explicit lampoons of her political views and personal conduct. In an effort to protect these satires of a public figure, the court used language from each of the standards outlined. The court also expressed uncertainty about whether the various tests were applicable to a determination of defamatory content or opinion, and cited the confusion of various courts as to the relation between the two standards. Id. at $1414 \& \mathrm{n} .7$. The Dworkin lampoon may be distinguished from protected political speech, however, if it is considered pornography. The countervailing interest of protecting the safety of women who are victimized by pornography, see Attorney General's Commission on Pornography, Final Report 323-35 (1986); Public Hearings on Ordinances to Add Pornography as Discrimination against Women, Minneapolis City Council, Gov't Opers. Comm. (Dec. 12-13, 1983), and the goal of promoting sex equality, see A. Dworkin \& C. Mackinnon, Pornography and Givil Rights: A New Day for Women's EQUaLITY (1988), may outweigh the speech value of pornography. Moreover, this pornography may be closer to false fact than opinion, and hence may not warrant protection as political speech. Using an approach somewhat analogous to the actual reader test proposed in this Note, see infra notes 118-19 and accompanying text, Catharine MacKinnon and Penelope Seator have argued that actual consumers of porn believe its underlying statement to be that all women desire to be raped, and believe that statement as fact rather than opinion. Brief of Amici Curiae in Support of PlaintiffAppellant at 10, 13, Dworkin, 867 F.2d 1188 (9th Cir. 1989) (No. 87-6393) (citations omitted). 


\section{SAtire as Protected Opinion}

\section{A. The Role of the Reader in Hermeneutics}

In developing a standard for identifying material that will fall into the protected satire category, hermeneutics is a useful tool. Because hermeneutics illuminates our cultural assumptions about meaning, it can explain how we derive meaning from texts. It can shed light on why the New York Times rule developed as it did. More importantly, the discipline of hermeneutics explores the processes that properly ought to be used to derive meaning. New trends in hermeneutics can therefore serve as a guide in shaping a new understanding of the opinion privilege.

Traditional hermeneutics, which centered on interpreting the Bible, attempted to recapture the meaning placed in a text by the author. ${ }^{84}$ Interpretation represented an endeavor to recreate the original creative act; it used the text as a means for communicating with the original writer. ${ }^{85}$

The New York Times test utilizes the three elements that are the subject of debate in hermeneutics-text, reader, and author ${ }^{86}$-but in line with the traditional approach, concentrates on authorial intent. Courts applying the standard examine the text to determine whether the material is a false statement of fact, and examine the reader's-or the microcosm of society, the judge and jury's-interpretation, asking whether the text is understood by audiences as defamatory; but the crux of New York Times, the actual malice rule, looks to authorial intent.

Modern hermeneutists, however, increasingly have looked to the subjective understanding of the reader. ${ }^{87}$ These theorists maintain that there is no objective way to explicate either a text's meaning or its author's intent, but rather that any such identification is made subjectively by a reader.

84. J. Bleicher, Contemporary hermeneutics 12 (1980).

85. See id. at 14.

86. This debate has been echoed in legal circles recently in discussions of how to read the Constitution. Former Attorney General Edwin Meese decries "pouring new meaning into old words," and instead looks to "[t]he text of the document and the original intention of those who framed it [for] the judicial standard in giving effect to the Constitution." E. Meese, Speech before the American Bar Association (July 9, 1985), reprinted in The FEDERALIST SocieTY, The Great Debate: INTERPRETING OUR WRITTEN CONSTITUTION 1, 1, 10 (1986). Justice Brennan, by contrast, points to the modern reader as the locus for finding the current meaning of the Constitution: "Like every text worth reading, [the Constitution] is not crystalline .... This ambiguity of course calls forth interpretation, the interaction of reader and text. . . . We current Justices read the Constitution in the only way that we can: as Twentieth Century Americans." W. Brennan, Speech to the Text and Teaching Symposium (Oct. 12, 1985), reprinted in ThE FeDERAlist SocieTY, supra, at 11, 17. See also Powell, supra note 18, at 889-923 (exploring conflicting hermeneutic traditions that lent backdrop to drafting of Constitution).

87. Professor Hans-Georg Gadamer's theory of the "fusion of horizons" represents one aspect of this movement toward increased subjectivity; for Gadamer, interpreting a text is a dialogue between reader and text, rather than a search into the author's intent. H. GADAMER, TRUTH AND METHOD 358 (1975). Perhaps Justice Brennan's point that the "right to receive ideas follows ineluctably from the sender's First Amendment right to send them" is also a reflection of this trend. Board of Education v. Pico, 457 U.S. 853, 867 (1983) (emphasis omitted). But see E.D. Hirsch, JR., VAlidiTY IN INTERPRETATION 26 (1967) ("the only compelling normative principle . . . is the old-fashioned ideal of rightly understanding what the author meant"). 
Accordingly, many theorists no longer take the text or authorial intent to be constitutive of meaning, but instead focus on the audience's interpretation of the text. ${ }^{88}$ Professor Stanley Fish identifies the community of readers as the body responsible for determining how we read, understand, and interpret a text, and thus, what the text means. ${ }^{89}$ Contemporary legal doctrine should reflect this shift in identifying the locus for meaning.

\section{B. The Satire Test}

A proper test for the satire exemption would be fashioned on the three traditional elements of interpretation utilized in New York Times, but modified to reflect the lessons of contemporary philosophical and literary hermeneutic theory. The focus therefore would shift from authorial intent to the readers' understanding of the work's message. This approach is particularly apt for libel law, since defamation is only meaningful in terms of the community's perception of an individual's reputation. ${ }^{90}$ By using audience reaction to determine whether to apply the opinion privilege, courts could resolve the believable/believed dilemma: Only statements believed by the audience as fact would be subject to liability. ${ }^{\text {91 }}$

In determining whether a potentially libelous statement falls under the satire category of protected opinion, courts should begin by examining the text in its context and ask, first, is it satire? Second, did the author intend for the piece to be satire? Third, and most important, did audiences un-

88. Professor James Boyd White calls for "the idea of an interaction between mind and text." J.B. White, When Words Lose Their Meaning 18 (1984). According to White, the role of the reader is especially pronounced in interpreting satire: Swift's $A$ Tale of a Tub, for example, immerses the reader "in a crazed and impossible world in which he has to make his own way. ... The ultimate meaning of this text thus literally is the person the reader makes himself as he responds to it." Id. at 115. Even Professor Wayne Booth, who takes a more traditional approach-calling authorial intent the "court of final appeal," W. Booth, supra note 12, at 11 -relies on the reader when he describes how the meaning of irony and, implicitly, other forms of satire, is formed: "[T]he reader will find himself choosing ... to accept or reject the pose, or stand .... But irony dramatizes this choice, forces us into hierarchical participation, and hence makes the results more actively our own." Id. at 41 .

89. "II]t is interpretive communities, rather than either the text or the reader, that produce meanings and are responsible for the emergence of formal features." S. FisH, supra note 18, at 14. Professor Robert Cover discusses the role that readers in communities play in developing the proliferation of meanings for law. Cover, supra note 18, at 15, 17 n.47, 42. Justice Brennan, in consonance with Fish's theory, identifies the role of the community of readers in establishing meaning: "My relation to this great text is inescapably public. ... When Justices interpret the Constitution they speak for their community, not for themselves alone. . . . [I]t is, in a very real sense, the community's interpretation that is sought." W. Brennan, supra note 86 , at 13-14.

90. One article has noted the inappropriate intent focus of the actual malice test for libel, but does not develop the reader approach for the opinion privilege and even calls the fact/opinion distinction "trivial." Bezanson \& Ingle, Plato's Cave Revisited: The Epistemology of Perception in Contemporary Defamation Law, 90 DICK. L. REv. 585, 606-07 (1986).

91. Before the opinion privilege was constitutionalized, a 1949 Harvard Law Review Note advocated relying on the reader to distinguish between fact and fair comment, but only developed the standard in the most general sense: "If a substantial number of readers would understand the statement to rest solely on the opinions of the person making the statement, the statement should be regarded as comment and should come within the privilege if the matter is one of public interest." Note, Fair Comment, 62 HaRv. L. REv. 1207, 1213 (1949). 
derstand it as satire-was it perceived as factual, or was it taken as a subtle, artistic ${ }^{22}$ communication of an underlying opinion through the vehicle of seemingly factual assertions? Given the importance of protecting political satire, a plaintiff should be required to prove that the statement in question fails all three prongs of the test before liability could attach. ${ }^{93}$

Before developing the test in greater detail, two objections must be addressed. First, the reader approach to distinguishing opinion from fact may be objected to because of its "vagueness." ment, the reader approach renders the outcome unpredictable by placing the satirist in the precarious position of guessing how her work will be received-whether her readers will "get it"-and thereby exercises a chilling effect on satirists. ${ }^{95}$ Such uncertainty would be particularly problematic for realistic satire and for very dry, sophisticated statements such as Jonathan Swift's writings, which were believed by some readers. ${ }^{96}$

This argument can be met in several ways. First, the proposed test would protect the satirist even in extreme situations because it includes authorial intent as one of its three factors. All three elements remain, but with a shift in emphasis. Second, because the intent examined under the proposed standard is intent to satirize, rather than intent to falsify as under the actual malice test, the proposed rule affords greater protection to satiric material, by definition intentionally false.

A third response to the vagueness argument against the reader approach is that the writer is herself a member of the community of readers. Satire is an art form that depends upon shared assumptions between writer and reader. ${ }^{87}$ The satirist should not be surprised by her audience's

92. The Supreme Court has held artistic expression to be protected under the First Amendment. See, e.g., Schad v. Mt. Ephraim, 452 U.S. 61, 65 (1980). This Note does not dwell on the First Amendment status of artistic expression, however, since satire about public figures should be protected as political speech, whether or not it constitutes art. See Polygram Records v. Superior Court, 170 Cal. App. 3d 543, 555 n.14, 216 Cal. Rptr. 252, 259 n.14 (1985) (degree of artistic merit of work irrelevant to its protection).

93. Alternatively, if the defendant shows that the statement is satire on the basis of any of the three grounds, the statement should be protected. The initial burden, however, is on the plaintiff. See RESTATEMENT, supra note 57 , at $\$ 580 \mathrm{~A}$ comment e (plaintiff has burden of proving actual malice).

94. See Note, The Fact-Opinion Distinction in First Amendment Libel Law: The Need for a Bright-Line Rule, 72 GEO. L.J. 1817, 1846 (1984).

95. Indeed, it is arguable that the genius of the New York Times test lies in its choice of the author as the real judge of the statement. Through the intent-based actual malice standard, if an author thinks her statement is true, she can publish it without fear of liability.

96. See Jonathan Swift: A Critical Anthology 51 (D. Donoghue ed. 1971) (citing letter from John Arbuthnot to Jonathan Swift (Nov. 5, 1726)) ("IA] master of a ship [said] that he was very well acquainted with Gulliver, but that the printer had mistaken, that he lived in Wapping and not in Rotherhith. I lent the book to an old gentleman, who went immediately to his map to search for Lilliput."). The readers of the audience Swift was primarily addressing, however, understood that Swift's work was satire. Id. at 71-72 (citing Deane Swift, AN EsSay Upon THe Life, Writings and Character of DR. Jonathan SwifT (1755)) (Gulliver's voyage to Lilliput . . . is entirely political. His meaning . . . is to be found so very near the surface that it would almost be an affront to the common reason of those who are at all versed in the affairs of the world to offer any further explication.").

97. "[T]he writer addresses the reader, in part, as someone who shares his problem as a member 
reaction, but should have a sense of what her readers will understand. Finally, the jury is unlikely to miss the point of the satire under this test for a similar reason; the jurors will read the statement against the background of the interpretive assumptions of the reading community. The jurors should be instructed to view the work not through their own eyes, but as members of the audience to whom the satire was addressed. ${ }^{98}$ In the Hustler case, for example, the jury would be asked to consider whether actual Hustler readers understood the ad parody as fact or as satiric opinion. This aspect of the test reduces the possibility that the jury will misinterpret the satire.

Another objection that might be raised against the proposed test is that it violates contemporary hermeneutics to consider the text and the author at all when determining meaning. ${ }^{99}$ The reader's interpretation, however, cannot be understood in a vacuum without examining both the text and the author's intent. Assumptions about both are essential parts of the contextual backdrop for reading satire. A court must examine a text in order to determine how the audience addressed would read that text. The court must also look to authorial intent, because the reader's interpretation is based in part upon assumptions about the meaning that the author is trying to convey. ${ }^{100}$

\section{Factor 1: The Text}

A definition of satire based on the text may be drawn from literary criticism of the genre. The seventeenth century English poet John Dryden took the two essential components of satire to be wit and morality. ${ }^{101}$ Sat-

of the same culture." J.B. WhrTE, supra note 88 , at 281 . Professor White sees cultural commonality as particularly important in the case of satire: "Because humor involves the perception of the incongruous, it also involves the implicit assertion of shared congruities; otherwise it could not be understood." Id. at 121. The importance of shared contexts between author and reader cannot be stressed enough. See W. Bootr, supra note 12, at 13,28, 33 (irony is "communal achievement" that joins "kindred spirits" through "appeal to assumptions, often unstated, that ironists and readers share"); Fish, Don't Know Much About the Middle Ages: Posner on Law and Literature, 97 YALE L.J. 777, 783 (1988) ("[T]he constraints [on interpreting a text] will inhere . . . in the cultural assumptions within which both texts and contexts take shape for situated agents."). Professor Gadamer analyzes the significance of context through his concept of "horizons"--systems of typical expectations held by various actors in the reading process that are fused in the constitution of meaning. H. GADAMER, supra note 87 , at $269-74,358$.

98. See infra notes $117-19$ and accompanying text.

99. Later "reader-response critics," who deny the possibility of objective texts and indeed objectivity altogether, might level such a criticism. See READER REsponse Criticism xxv (J. Tompkins ed. 1980).

100. See Fish, supra note 97, at 778 ("Words are intelligible only within the assumption of some context of intentional production, some already in-place pre-decision as to what kind of person, with what kind of purposes in relation to what specific goals in a particular situation, is speaking or writing."). A reliance on authorial intent apart from the reader's perception of that intent is also important in order to shield the satirist from suit where her statement fails in its attempt to draw upon context and shared assumptions and is indeed believed as fact.

101. 2 Essays of John DRYden 75, 91 (W. Ker ed. 1900). By "wit," the literary critic Alvin Kernan interprets Dryden to mean " 'delight,' 'pleasure,' 'art." " A. Kernan, The Plot of Satire 7-8 (1965). Because some satire may be artless, see supra note 92 , this Note focuses on the sense of 
ire thus can be identified first by the methods it employs; whether in the form of irony, sarcasm or parody, it is usually humorous, and uses shocking and cruel language. ${ }^{102}$ It touches on matters often fantastical, but not unthinkable ${ }^{103}$-improbable but not impossible. Satire uses rhetorical forms in which reality and appearance constantly shift. ${ }^{104}$ But, second, it jokes at serious things. ${ }^{108}$ The moral element of which Dryden wrote is found in satire's didactic purpose, its effort to effect change. ${ }^{106}$

Courts should utilize this analysis in determining whether the textual elements of a satire are present in a contested statement. First, courts should examine the methods used in the piece. Does the communication use distortion, with an element of humor? Second, does the piece convey a message critical of political or social phenomena? Courts, however, should examine neither the level of humor achieved ${ }^{107}$ nor the value of the message. ${ }^{108}$ First Amendment protection is not limited to statements which are "constructive" in public debate. ${ }^{109}$

In examining the text of an allegedly defamatory statement, the totality of circumstances test also may be useful to courts. ${ }^{110}$ Finally, courts should be careful not to look to the facial, seemingly factual message of a satiric piece ("Falwell has incestuous relations"), but instead focus on its underlying point-the opinion ("Falwell is a hypocrite"). ${ }^{111}$

"wit" as "delight," or humor. Cf. Frye, The Mythos of Winter: Irony and Satire, in Modern SATIRE 155-56 (A. Kernan ed. 1962) ("Two things . . . are essential to satire: one is wit or humor founded on fantasy or a sense of the grotesque or absurd, the other is an object of attack.") (emphasis added).

For a detailed look at the textual clues of irony, one of the forms that satire takes, see W. Boorf, supra note 12, at 49-86 (clues include warnings in author's own voice, known errors, conflicts of facts, style or beliefs, and context).

102. G. Higher, supra note 7 , at $5,18,55-72$.

103. Id. at 60 .

104. A. KERNAN, supra note 101 , at $16-17,23$.

105. Id. at 233.

106. E. Bloom \& L. Bloom, Satire's Persuasive Voice 18 (1979); see also G. Highet, supra note 7 , at 234,238 (satire's function is social reform, to cure or execute, to tell truth). It is because of this characteristic that satire lends itself to political speech.

107. See supra notes 73-79 and accompanying text.

108. Some courts and commentators have taken this dangerous approach. See, e.g., Miss America Pageant v. Penthouse Int'l, Ltd., 524 F. Supp. 1280 (D.N.J. 1981); Hustler, Brief for Respondent, supra note 32, at 21; Comment, Defamation: Problems with Applying Traditional Standards to Non-Traditional Cases-Satire, Fiction, and "Fictionalization," 11 N. Kx. L. Rev. 131, 141-43 (1984).

109. Pring v. Penthouse Int'l, Ltd., 695 F.2d 438, 443 (10th Cir. 1982). The problem with examining value is that a valuable contribution in the eyes of some may be vulgar and worthless to others.

110. See supra notes 49-58 and accompanying text. One commentator, see Note, supra note 94, advocates conditioning protection for opinion upon the inclusion of cautionary terms such as the disclaimer used in Falwell, see supra note 32 . While warnings in the author's own voice may indicate that a statement is opinion, such a "mechanical, bright-line rule" would not suffice in an area where distinctions are vague and complex. Ollman v. Evans, 750 F.2d 970,978 (D.C. Cir. 1984) (en banc), cert. denied, 471 U.S. 1127 (1985). Satirists, for example, may distort such clues for effect. See also Falwell, 805 F.2d at 486 (disclaimer "did not and should not convey upon Flynt some magical immunity from suit"); Cianci v. New Times Publishing Co., 639 F.2d 54, 64 (2d Cir. 1980) (writer cannot escape liability simply by prefacing statement with "I think").

111. First Amendment attorney Robert Sack notes that the opinion privilege is the most promising means of protecting intentional falsehoods such as humor and fiction, but that courts could defeat the intended protection by applying the privilege too literally-by looking to the surface message, finding 


\section{Factor 2: The Author's Intent}

The actual malice standard is of little value in examining the intent of satirists, since knowledge of falsity is a defining feature of satire, and hence is easy for plaintiffs to establish. Common law malice-spite or ill will-also is unhelpful. ${ }^{112}$ Nor is it appropriate to ask if the defendant intended to target the plaintiff; ${ }^{113}$ the satirist, as social/political commentator, frequently intends to target individuals and expose their follies. ${ }^{114}$ Finally, as discussed above, the intent-based test used by the Supreme Court in Hustler, asking whether a statement can be found to "describe" facts, also is faulty.

Instead, courts should seek to determine, insofar as is possible, whether the speaker or author had an intent to satirize: whether she tried to criticize a public figure or event through distortion and humor. ${ }^{115}$ If intent to satirize is found, even where combined with maliciousness or spite, the author should not be held liable.

\section{Factor 3: The Reader's Interpretation}

Courts have relied inappropriately on the audience's reaction to a potentially libelous statement to determine whether it is an outrageous or a believable description of actual events. The question of whether the reader finds the statement defamatory also is not probative, since opinions can be defamatory. Rather, courts should ask whether the text functions as satire:

an assertion of fact and missing the underlying point of the text. R. SACK, supra note 14, at 246-47. The importance of this distinction has been recognized by at least one court, see Yorty v. Chandler, 13 Cal. App. 3d 467, 472-74, 91 Cal. Rptr. 709, 712-13 (1970), as well as by theorists in one branch of hermeneutics, semiotics, which investigates the interaction of signs in the creation of meaning, see J. Fiske, InTroduction to Communication Studies 90-91 (1982) (analyzing Roland Barthes' theory distinguishing between first order signification, "denotation," and second order signification, "connotation").

112. The Supreme Court has rejected the relevance of common law malice. See Hustler, $108 \mathrm{~S}$. Ct. at 880; Old Dominion Branch No. 496, Nat'l Ass'n of Letter Carriers v. Austin, 418 U.S. 264, 281 (1974). Moreover, literary theorists criticize the "biographical approach" to understanding satire, since satire is not a form of personal attack born of authors' prejudices or their physical, psychic and social difficulties. A. KERNAN, supra note 101, at 4-5. In any event, it is extremely difficult-if not impossible-to ascertain the satirist's true motivations. See L. FEINBERG, supra note 10, at 15, 241-42, 353-55 (undertaking psychological study of satirists). Freud took the view that no wit is entirely intentional, but rather derives involuntarily from the unconscious, S. FreUD, JOKES AND Their Relation to THE Unconscious 167-69 (J. Strachey ed. 1960); similarly, the ancients thought that art speaks through the artist, see L. FeINBERG, supra, at 4-5.

113. Reverend Falwell, for example, argued that Flynt's desire to "assassinate" his character was critical. Respondent's Brief in Opposition at 3, Hustler and Flynt v. Falwell, 108 S. Ct. 876 (1988) (No. 86-1278).

114. In satire, character assassination is the author's aim. Hustler, $108 \mathrm{~S}$. Ct. at 881 (satire is calculated to injure); W. BooTH, supra note 12 , at 28 (satire has victims).

115. Intent should be examined regarding content-the message, or ideational aspect-as well as matters of presentation, such as the intended genre, tone and audience. The "audience addressed" aspect of the totality of circumstances test, see supra note 50, recognizes the importance of considering the author's intentional act of targeting her work for an interpretive community that shares her expectations about genre and hence is likely to understand her work. 
Is it believed, understood literally as a factual assertion, or do its readers see it as a tongue-in-cheek, critical opinion ? $^{116}$

Jurors, however, must ask themselves not how they view the text, or how "ordinary readers" would perceive it, ${ }^{117}$ but rather how the actual readers of such material read and would read the text. ${ }^{118}$ The relevant audience is one that is literate in the particular type of writing, and that has certain genre expectations when reading the type of material in dispute. ${ }^{119}$ Only if the plaintiff gives clear and convincing evidence ${ }^{120}$ that a substantial number ${ }^{121}$ of the actual readers believed the statement as fact

116. The definition of satire developed by literary theorists is helpful in explicating readers' interpretations. Courts should ask whether the reader finds in the publication both the methods of distortion and/or humor, as well as a moral message-a political or social critique. See supra notes 101-106 and accompanying text. Analyses of the process of reading satire also are useful. Theorists tell us that satire evokes emotions of both amusement and contempt in its recipients. G. HIGHET, supra note 7, at 21, 150; see also W. BooTH, supra note 12, at 10-12 (describing process of reading irony).

117. Where courts have focused on the readers' interpretation in defamation suits, they have looked to the "average," "reasonable" or "rational" reader's reaction to statements, rather than the "actual" reader's "actual" reaction. Saenz v. Playboy Enter., 653 F. Supp. 552, 565 n.2 (N.D. Ill. 1987); see, e.g., Ollman v. Evans, 750 F.2d 970, 979 (D.C. Cir. 1984) (en banc) (average reader) cert. denied, 471 U.S. 1127 (1985); Buckley v. Littell, 539 F.2d 882, 894 (2d Cir. 1976) (ordinary reader), cert. denied, 429 U.S. 1062 (1977). This approach reflects the widely used reasonable person standard. See W. Prosser \& W. Keaton, The Law of Torts $\$ \$ 32-33$ (5th ed. 1984).

118. Juries should be instructed to consider evidence of how the material was in fact received by its actual audience. Few courts have taken this approach. See Old Dominion Branch No. 496, Nat'l Ass'n of Letter Carriers v. Austin, 418 U.S. 264, 285 (1974) (no evidence that statement was understood by any readers of newsletter to be making factual accusation); Rudin v. Dow Jones \& Co., 557 F. Supp. 535 (S.D.N.Y. 1983) (plaintiff labelled by Barron's magazine as "mouthpiece" for Frank Sinatra; Barron's readers polled as to their understanding of term "mouthpiece"); Reddy Communications v. Environmental Action Found., 477 F. Supp. 936, 947 (D.D.C. 1979) (trademark infringement case involving parody of plaintiffs service mark; survey evidence brought by plaintiff found methodologically flawed because it failed to inform interviewees of nature of publication and surrounding text, and "to account for the specific public exposed to EAF publications. Indeed, the . . . survey, in all likelihood, did not include one actual reader of EAF publications.") (emphasis added). The relevant group would be composed of actual readers from the intended audience, not casual bystanders. $C f$. Bose Corp. v. Consumers Union of United States, Inc., 508 F. Supp. 1249, 1265 (1981) (product disparagement claim by manufacturer of loudspeaker; "there is no evidence to suggest that the words used would have any unusual meaning to any particular group, such as audiophiles, who might have more interest in the Article than the general public"), rev'd on other grounds, 466 U.S. 485 (1984).

The actual reader approach is more appropriate than the reasonable reader standard in the defamation context because the meaning of an allegedly defamatory statement is created by the actual, particularized reader, not a hypothetical one. See D. Morley, The Nationwide Audience: StrucTURE AND DECoDING 163 (British Film Institute 1980) (empirical study of subcultural groupings and effect of their particular frameworks and individual readings on meaning formation). This approach is analogous to arguments for a more subjective understanding of the reasonable person standard. Cf. Minow, The Supreme Court, 1986 Term-Foreword: Justice Engendered, 101 HaRv. L. REv. 10 (1987) (courts should strive to understand perspective of individual and her difference, particularly where law is concerned to protect minority viewpoints).

119. A reader's interpretation is in part conditioned by what the reader expects to find in the text, based on her reading of similar texts in the past. See Ollman, 750 F.2d at $983 \&$ n.25 (one factor of context is "power of . . . genres . . . to influence the audience's view of a statement"); W. Booth, supra note 12, at 100 (discussing importance of audience's genre expectations).

120. The actual malice standard requires clear and convincing evidence regarding the author's intent at trial, see Bose Corp., 466 U.S. at 511 n.30, as well as at summary judgment, Anderson v. Liberty Lobby, Inc., 477 U.S. 242 (1986). Likewise, the satire privilege should require clear and convincing evidence regarding the readers' interpretation.

121. For a communication to be defamatory, it must prejudice the subject in the eyes of a "sub- 
rather than as satiric opinion, or if the jurors acting as surrogate readers believe the statement as fact, should liability be permissible. ${ }^{\mathbf{1 2 2}}$

\section{CONCLUSION}

Judge Learned Hand once wrote: "It is indeed not true that all ridicule ... or all disagreeable comment . . . is actionable; a man must not be too thin-skinned or a self-important prig." ${ }^{123}$ In New York Times and Gertz, the Supreme Court developed a constitutional standard to protect critics from libel claims based on mistaken fact or opinion, even where such opinion is "disagreeable comment." That standard and the various interpretations of it developed by the courts have proven clumsy and unworkable when applied to satire. Satire is not adequately protected under New York Times, which focuses on intent, or under current understandings of the opinion privilege, which focus on the text of the communication and its context. Courts should recognize a new category for satire under the opinion privilege. The proposed satire test would utilize, as does the New York Times standard, all three elements recognized by traditional hermeneutics as constitutive of meaning-text, authorial intent and readers' interpretation-but emphasize, in accordance with the developments of contemporary hermeneutics, the community's interpretation of the statement as believed fact or as opinion.

stantial and respectable minority" of the community. RESTATEMENT, supra note 57 , at $\$ 559$ comment e.

122. In establishing the respective roles that the court and jury should play in the process of making the fact/opinion distinction for satire, the proposed standard should function in a fashion similar to that used to determine both the fact/opinion dichotomy generally and defamatory content. In the first instance, these determinations are questions of law for the courts, Ollman, $750 \mathrm{~F} .2 \mathrm{~d}$ at 978 (citing Lewis v. Time, Inc., 710 F.2d 549, 553 (10th Cir. 1983)) (on fact/opinion); ResTatemENT, supra note 57 , at $\$ 614$ comment $\mathrm{c}$ (on defamatory content), and if the meaning of the statement is found to be ambiguous, it is a question of fact for the jury, Myers v. Boston Magazine Co., 380 Mass. $336,339,403$ N.E.2d 376, 378 (1980). Using the factors outlined above, the judge would ask, based on her own interpretation of the allegedly defamatory statement: Could the text be considered satire? Could the author be said to have intended it to be satire? And could it be understood as satire, or must it be seen as a factual claim? On summary judgment, the judge might find that the material clearly is satire and could not reasonably be believed as fact. If the piece is found by the court to be ambiguous in its believability, however, the determination of whether it is to be protected as satiric opinion is for the jury to decide, following the actual reader standard proposed in this Note. On appeal, de nowo review would be required, as with the actual malice standard. Bose Corp., 466 U.S. at $508-11$.

123. Burton v. Crowell Publishing Co., 82 F.2d 154, 155 (2d Cir. 1936) (nevertheless finding liability for ridicule). Judge Hand used a modified version of the proposed reader test in evaluating the allegedly defamatory statement in that case. At a luncheon during the time Judge Hand "was studying the case on appellate review, ... he pulled the advertisement out of his brief case and without any comment passed it around the table. As we looked at it we burst into roars of laughter. 'That settles it,' said Judge Hand. 'It's defamatory.' " L. Eldredge, The Law of Defamation 39 (1978). 